\title{
EFFECT OF MECHANICAL PROPERTIES ON SAP AS PARTIAL REPLACEMENT OF CEMENT FOR M-25 CONCRETE
}

\author{
${ }^{1}$ Shreya Upadhyay ${ }^{2}$ Siddharth Pastariya ${ }^{3}$ Anant Bharadwaj ${ }^{4}$ Shantanu Mehta \\ ${ }_{1}^{1}$ M.Tech Scholar, Department of Civil Engineering, Sri Aurobindo Institute of Technology Indore M.P. \\ ${ }^{2}$ Assistant Professor, Department of Civil Engineering, Sri Aurobindo Institute of Technology Indore M.P. \\ ${ }^{3}$ Assistant Professor, Department of Civil Engineering, Sri Aurobindo Institute of Technology, Indore M.P. \\ ${ }^{4}$ Assistant Professor, Department of Civil Engineering, Sri Aurobindo Institute of Technology, Indore, M.P. \\ $* * *$
}

\begin{abstract}
Conventional concrete require water curing for a minimum of 28 days to complete its target strength. Therefore water curing is very much necessary to prevent unsatisfactory properties of cement concrete. In order to have good quality curing, surplus of evaporation from the surface need to be prevented. Self-curing concrete is one of the extraordinary concrete which is gaining importance in recent days as it avoid errors which were caused by human, structures which are not available, terrains where curing becomes complicated and in places where the fluoride content badly influences the property of concrete Plain concrete needs pleasant atmosphere by providing moisture for a minimum period of 28 days for good hydration and to attain desired strength. Self curing concrete is the one which can cure itself by retaining its moisture content. In the this research, the affect of admixture (SAP) on compressive strength, by varying the percentage of SAP by weight of cement from $0 \%, 0.8 \%, 1.6 \%, 2.4 \% \& 3.2 \%$ are studied for M25 mixes
\end{abstract}

Keywords: SAP, Water cement ratio, Compressive strength, Flexural Strength, Tensile Strength

\section{INTRODUCTION}

Proper curing of concrete structures is very important to fulfill performance and durability necessities. In typical curing this can be achieved by external curing applied when combination, putting and finishing. Self-curing or internal curing could be a technique that may be wont to give extra wetness in concrete for simpler hydration of cement and reduced self-desiccation. The ACI-308 Code states that "internal curing refers to the method by that the association of cement happens due to the supply of extra internal water that's not a part of the blending water". the extra internal water is usually provided by using comparatively little amounts of saturated, lightweight weight, polythene Glycol, super absorbent chemical compound particles within the concrete.

\section{MATERIAL USED}

2.1 Cement: Portland Pozzolana cement (PPC) is used in this research work.
$* * *$

2.2 Sand: Sand is available near Narmada River. This sand is used for the above research work.

2.3 Natural aggregate: $20 \mathrm{~mm}$ natural coarse aggregate is used having a specific gravity of 2.72 .

2.4 Super Absorbent polymer (SAP): The common SAPs are added at rate of $0.2,0.3$ and $0.4 \mathrm{wt} \%$ of cement. The SAPs are covalently cross-linked. They are Acryl amide/acrylic acid copolymers. One type of SAPs are suspension polymerized, spherical particles with an average particle size of approximately $1.00 \mathrm{~mm}$; another type of SAP is solution polymerized and then crushed and sieved to particle sizes in the range of $0.50-2.00 \mathrm{~mm}$. The size of the swollen SAP particles in the cement pastes and mortars is about three times larger due to pore fluid absorption. The swelling time depends especially on the particle size distribution of the SAP. It is seen that more than $50 \%$ swelling occurs within the first $5 \mathrm{~min}$ after water addition 


\section{AND ENGINEERING TRENDS}

Table 1: Properties of Super Absorbent Polymer

\begin{tabular}{|c|c|}
\hline Particle size & 1 mm(Average) \\
\hline $\begin{array}{c}\text { Water absorption with } \\
\text { distilled water }\end{array}$ & $150 \mathrm{~g}$ for 1 g of SAP \\
\hline $\mathrm{pH}$ of absorbed water & Neutral \\
\hline Density & 1.08 \\
\hline Bulk density & 0.85 \\
\hline Hydration / Dehydration & Reversible \\
\hline Decomposition in sun \\
light
\end{tabular}

\section{EXPERIMENTAL WORK AND TEST}

3.1 Mix Design for M-25 Grade: The proportion of M-25 grade concrete is calculated as per IS 10262-2009 \& IS 4562000 is $1: 1.75: 2.75$. Water binder ratio is taken as 0.42 .

3.2 Compressive Strength Test: The mould is prepared for cubes used in the compression test having a size of $0.15 \mathrm{mX} 0.15 \mathrm{mX} 0.15 \mathrm{~m}$. After preparing cubes rest on the compression testing machine and load is applied. After applying load the value noted from the dial gauge. Compressive strength determine at $7 \& 28$ days.

3.3 Flexural Strength Test: The mould is prepared for beams used in the bending test having a size of $0.10 \mathrm{mX} 0.10 \mathrm{mX} 0.50 \mathrm{~m}$. After preparing beams rest on the flexural testing machine and load is applied. After applying load the value noted from the dial gauge. Bending strength determine at $7 \& 28$ days

3.4 Split Tensile Strength: The mould is prepared for cylinder used in the tensile test having a size of $0.15 \mathrm{~m}$ diameter and $0.30 \mathrm{~m}$ height. After preparing cylinder rest on the compression testing machine and load is applied. After applying load the value noted from the dial gauge. Tensile strength determine at $7 \& 28$ days

\section{TEST RESULTS}

4.1 Compressive Strength; The below table shows the compressive strength for different percentage of SAP which is vary from $0 \%-3.2 \%$.

Table 2: Compressive Strength Result

\begin{tabular}{|c|c|c|c|}
\hline $\begin{array}{c}\text { Mix } \\
\text { Design }\end{array}$ & \% SAP & $\begin{array}{c}\text { 7 days } \\
\text { Compressive } \\
\text { Strength }\end{array}$ & $\begin{array}{c}\text { 28 days } \\
\text { Compressive } \\
\text { Strength }\end{array}$ \\
\hline Mix-01 & 0 & 22.97 & 32.62 \\
\hline Mix-02 & 0.8 & 26.73 & 36.51 \\
\hline Mix-03 & 1.6 & 24.99 & 31.47 \\
\hline Mix-04 & 2.4 & 23.77 & 29.40 \\
\hline Mix-05 & 3.2 & 23.62 & 27.03 \\
\hline
\end{tabular}

4.2 Flexural Strength The below table shows the Bending strength for different percentage of SAP which is vary from $0 \%-3.2 \%$.

Table 3: Flexural Strength Result

\begin{tabular}{|c|c|c|c|}
\hline $\begin{array}{c}\text { Mix } \\
\text { Design }\end{array}$ & \% SAP & $\begin{array}{c}\text { 7 days } \\
\text { Flexural } \\
\text { Strength }\end{array}$ & $\begin{array}{c}\text { 28 days } \\
\text { Flexural } \\
\text { Strength }\end{array}$ \\
\hline Mix-01 & 0 & 3.8 & 5.34 \\
\hline Mix-02 & 0.8 & 4.56 & 6.54 \\
\hline Mix-03 & 1.6 & 4.38 & 5.96 \\
\hline Mix-04 & 2.4 & 4.28 & 5.90 \\
\hline Mix-05 & 3.2 & 4.21 & 5.56 \\
\hline
\end{tabular}

4.3 Split Tensile Strength The below table shows the tensile strength for different percentage of SAP which is vary from $0 \%-3.2 \%$. 


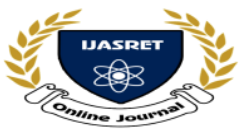

|| Volume 5 || Issue 12 || December 2020 || ISSN (Online) 2456-0774

INTERNATIONAL JOURNAL OF ADVANCE SCIENTIFIC RESEARCH

AND ENGINEERING TRENDS

Table 4: Tensile Strength Result

\begin{tabular}{|c|c|c|c|}
\hline $\begin{array}{c}\text { Mix } \\
\text { Design }\end{array}$ & \% SAP & $\begin{array}{c}\mathbf{7} \text { days Split } \\
\text { Tensile } \\
\text { Strength }\end{array}$ & $\begin{array}{c}\text { 28 days } \\
\text { Split Tensile } \\
\text { Strength }\end{array}$ \\
\hline Mix-01 & 0 & 3.39 & 4.95 \\
\hline Mix-02 & 0.8 & 4.88 & 6.64 \\
\hline Mix-03 & 1.6 & 4.38 & 6.01 \\
\hline Mix-04 & 2.4 & 4.17 & 5.65 \\
\hline Mix-05 & 3.2 & 3.74 & 5.51 \\
\hline
\end{tabular}

\section{DISCUSSION ON TEST RESULTS}

5.1 Compressive Strength Test: From the graph 1 it is conclude that $7 \& 28$ days compressive strength $22.8 \%$ \& $20.05 \%$ increases when percentage upto $0.8 \%$. After that strength decreases when percentage of SAP increases.

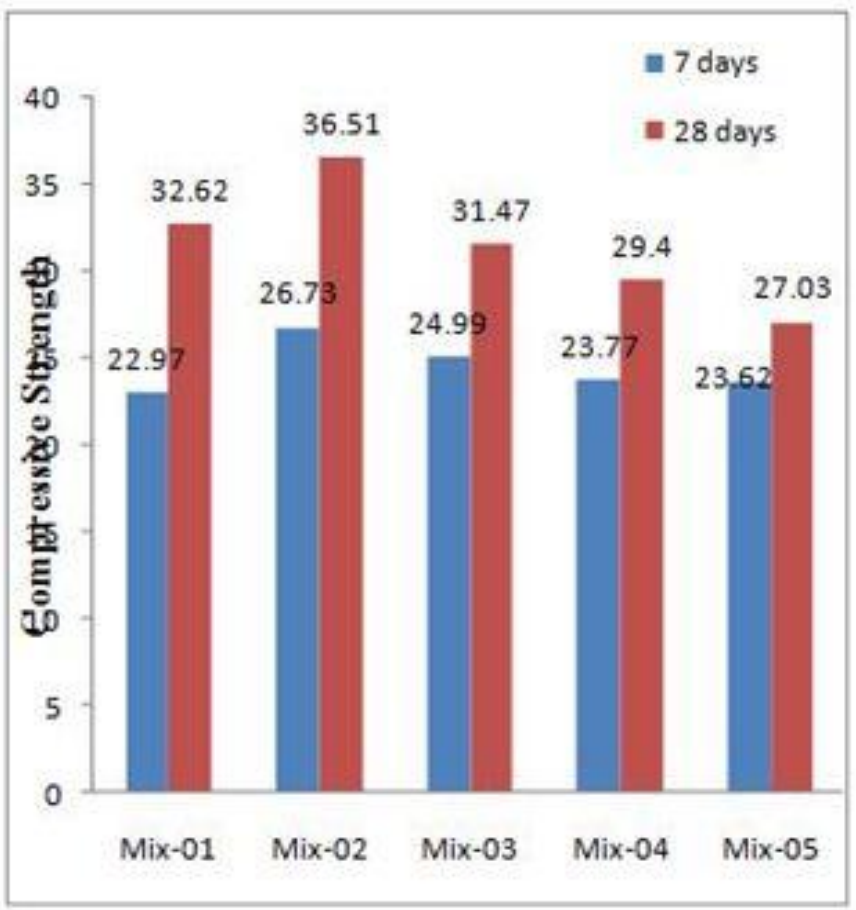

Graph: 1. Compressive Strength in N/mm2

5.2 Flexural Strength: It is conclude that $7 \& 28$ days bending strength $20 \%$ \& $22.47 \%$ increases when percentage upto $0.8 \%$. After that strength decreases when percentage of SAP increases.

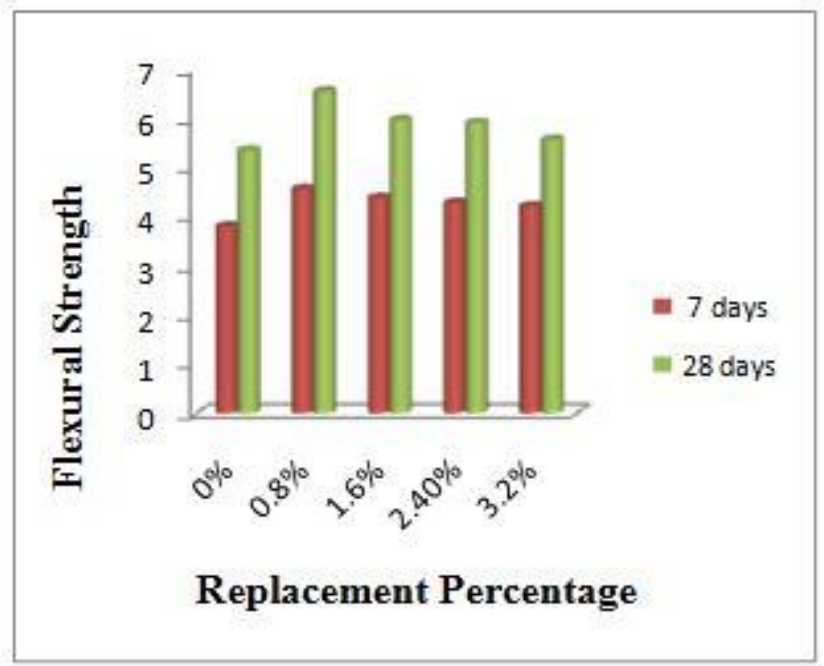

Graph:2 Flexural Strength in N/mm2

5.3 Split Tensile Strength: It is conclude that $7 \& 28$ days tensile strength $43.95 \%$ \& $34.19 \%$ increases when percentage upto $0.8 \%$. After that strength decreases when percentage of SAP increases.

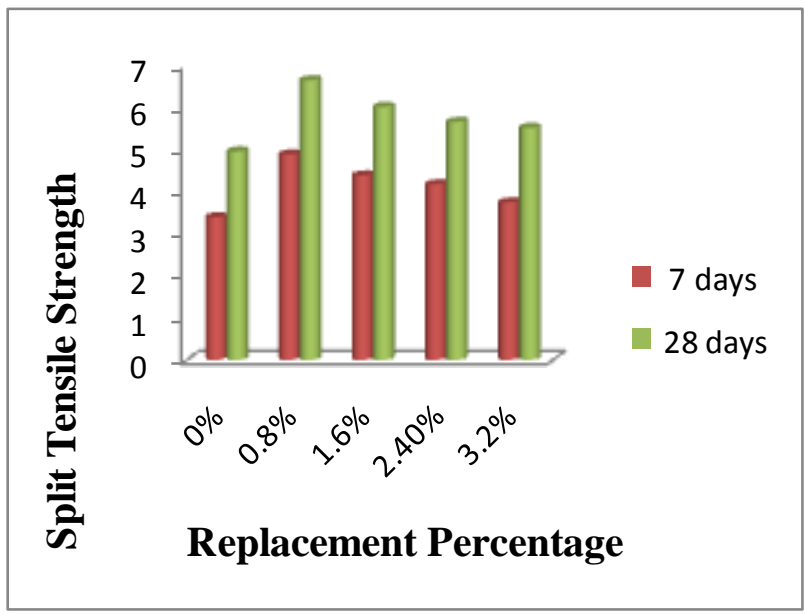

Graph 3: Split Tensile Strength in N/mm2

\section{CONCLUSIONS:}

Based on the various tests conducted on concrete with varying proportion of SAP the results were obtained and discussed in previous chapter from which the following conclusions are drawn.

1. 1. The compressive strength of concrete initially increases with replacement of cement with the SAP upto $0.8 \%$ and after that there is decrease in compressive strength of concrete with further replacement of cement as the mix became less cohesive and less workable. 


\section{|| Volume 5 || Issue 12 || December 2020 || ISSN (Online) 2456-0774 INTERNATIONAL JOURNAL OF ADVANCE SCIENTIFIC RESEARCH}

\section{AND ENGINEERING TRENDS}

2. Flexural strength of concrete with $0.8 \%$ replacement of cement with SAP is $2.47 \%$ greater than Flexural strength of normal concrete

3. Split tensile strength of concrete with $0.8 \%$ replacement of cement with SAP is $3.4 \%$ greater than split tensile strength of normal concrete.

4. From the result of this study it is recommended that $0.8 \%$ SAP is adequate for partial replacement of Cement in concrete for self curing concrete

\section{REFERENCES}

1. Siddharth Jain: Investigation of Strength Characteristics of Concrete by Replacing Curing Water with Self Curing Compounds International Journal of Engineering Technology, Management and Applied Sciences www.ijetmas.com July 2017, Volume 5, Issue 7, ISSN 2349-4476

2. S. Azhagarsamy1, Dr. S. Sundararaman2: A Study on Strength and Durability of Self Curing Concrete Using Polyethylene Glycol-400International Journal of Emerging Technology and Advanced Engineering Website: www.ijetae.com (ISSN 2250-2459, ISO 9001:2008 Certified Journal, Volume 6, Issue 1, January 2016)

3. Shreyash Shah1, Ashutosh Patil2: An Experimental Investigation of Effect of Variation of Curing Time on Compressive Strength of Concrete International Journal of Emerging Technology and Advanced Engineering Website: www.ijetae.com (ISSN 2250-2459, ISO 9001:2008 Certified Journal, Volume 5, Issue 3, March 2015)

4.Sachin Julian Francis\#1, B.Karthik*2, H.Gokulram\#3 Flexural Behaviour of Self-curing Concrete with Lightweight Aggregate and Polyethylene Glycol International Journal of Engineering Trends and Technology (IJETT) - Volume 47 Number 2 May 2017

5.Vishnu T Beena B R An Experimental Investigation of SelfCuring Concrete Incorporated with Light Weight Fine Aggregate and Polyethylene Glycol IJIRST -International Journal for Innovative Research in Science \& Technology| Volume 3 | Issue 04 | September 2016 ISSN (online): 2349-6010

6.Mohammad Suhail AN EXPERIMENTAL INVESTIGATION ON SELF-CURED CONCRETE: A REVIEW INTERNATIONAL JOURNAL OF RESEARCH IN TECHNOLOGY AND MANAGEMENT (IJRTM) ISSN 24546240
7.Mr. Sanjay raj A *, Yogananda N Experimental investigation on Self-Curing Self-Compacting Concrete by Replacing Natural Sand by M-sand and Coarse aggregates By Light Weight Aggregate for M-40 Grade Concrete International Journal of Scientific and Research Publications, Volume 4, Issue 8, August 20141 ISSN 2250-3153

8. K.S. Johnsirani*, Dr. A. Jagannathan**, R. Dinesh Kumar*** Experimental Investigation on Self Compacting Concrete using Quarry Dust International Journal of Scientific and Research Publications, Volume 3, Issue 6, June 20131 ISSN 2250-3153

9. Shikha Tyagi "AN EXPERIMENTAL INVESTIGATION OF SELF CURING CONCRETE INCORPORATED WITH POLYETHYLENE GLYCOL AS SELF CURING AGENT" International Research Journal of Engineering and Technology (IRJET) e-ISSN: 2395 -0056 Volume: 02 Issue: 06 | Sep-2015 www.irjet.net p-ISSN: 2395-0072

10. M. POOVIZHISELVI1, D.KARTHIK2 EXPERIMENTAL INVESTIGATION OF SELF CURING CONCRETE International Research Journal of Engineering and Technology (IRJET) e-ISSN: 2395 -0056 Volume: 04 Issue: 01 | Jan -2017 www.irjet.net p-ISSN: 2395-0072

11. 1Dadaji B. Jadhav, 2Ranjana Ghate, A STUDY ON SELF-CURING AND SELF-COMPACTING CONCRETE USING POLYETHYLENE GLYCOL International Research Journal of Engineering and Technology (IRJET) eISSN: 2395 -0056 Volume: 04 Issue: 02 | Feb -2017 www.irjet.net p-ISSN: 2395-0072

12.Remya K M1, Shilpa.V S 2, Dhanusha.M3, Ashna L Sukumar4 , Ashna ismayil5, Sreerag K6 Experimental Study on Strength Characteristics of Self Curing Concrete using Poly Ethylene Glycol and Light Weight Aggregate International Journal of Research in Advent Technology (EISSN: 2321-9637) Special Issue International Conference on Technological Advancements in Structures and Construction "TASC-15”, 10-11 June 2015

13.Sona K. S1., Irin Mary Martin2 Evaluation on Self Curing and Durability of ConcreteUsing Super Absorbent Polymer International Journal of Research in Advent Technology (E-ISSN: 2321-9637) Special Issue International Conference on Technological Advancements in Structures and Construction "TASC-15”, 10-11 June 2015 